\title{
METAPHORIC REPRESENTATION OF THE CONCEPT 'CRIME' IN THE U.S. MEDIA DISCOURSE
}

\author{
Oksana Oliinyk \\ Volodymyr Vynnychenko Central Ukrainian State Pedagogical University, \\ Kropyvnytskyi, Ukraine \\ roxyletters@gmail.com
}

\author{
Liudmyla Naumenko \\ Taras Shevchenko National University of Kyiv, Ukraine \\ v-naumenko@ukr.net
}

\begin{abstract}
This paper is a study of conceptual metaphors that represent the concept 'crime' in the contemporary U.S. media discourse. The theoretical background is based on Cognitive Theory of Metaphor by G. Lakoff that considers metaphor as a cognitive structure that helps understand a complex idea (the target domain) by assigning to it qualities found in a familiar/simple object (the source domain). The main question is how the notion 'crime' is conceptualised in the U.S. periodicals, thus shaping social views of it. In order to find an answer, a survey of 1213 fragments of 232 newspaper articles with metaphoric collocations naming the concept 'crime' has been conducted. By applying cognitive theory of metaphor analysis to metaphoric expressions, three types of conceptual metaphors have been singled out: structural, ontological, and orientation. The data suggest that orientation metaphors of the concept 'crime' are most pervasive in the U.S. media discourse (61\% of the total number of collocations), with structural metaphors occupying the second position (38\%), and ontological metaphors being the least frequent (1\%). Orientation metaphors feature the trajectory of crime in space: up - down, forward - backward, from the centre - to the centre, and are used to represent statistics of the crime rate. Structural metaphors 'crime is an enemy', 'crime is the element of nature', 'crime is a disease', 'crime is a weed', 'crime is goods', 'crime is a hazardous substance' model the strategies of crime rate reduction for ordinary Americans. Ontological metaphors 'crime is mire', 'crime is food', 'crime is a beast' highlight such cognitive features of crime as dirt, harm, and danger.
\end{abstract}

Keywords: concept 'crime'; conceptual metaphor; cognitive theory of metaphor; cognitive model; orientation, ontological, structural metaphors.

\section{"Metaphors [...] are among our principal vehicles for understanding" George Lakoff, Mark Johnson "The metaphor is the vehicle that carries the reader from a world of common objects, and their attendant qualities, to the realm of ideas". \\ Benjamin L. Berger}

\section{Introduction}

The cognitive linguistic paradigm advocates the understanding of linguistic metaphors more as a matter of thinking and reasoning rather than of language itself, that is mere figurative uses of expressions (Lakoff \& Johnson, 1980a, 1980b, 1980c; Johnson, 2010). According to Cognitive Theory of Metaphor (henceforth CTM), the conceptual metaphor (henceforth $\mathrm{CM}$ ) is a mental structure that helps an addressee "understand a complex idea by assigning to it qualities found in a familiar or simple object" (Berger, 2002, p. 34). In other words, CMs are cognitive models representing an equation between two domains: conceptual domain A (the target domain) and conceptual domain B (the source domain) (Kövecses, 2010, p. 4; Stevanovic, 2014, p. 129).

Although crime is a global phenomenon and part of people's social life, cultural differences and arbitrariness of language make its conceptualisation culture-specific. This paper explores conceptual metaphors of the concept of 'crime' operating within the U.S. media discourse.

\section{Literature Review}

Most current research on conceptual metaphors relating to the U.S. legal sphere falls into several thematic groups: (1) those "delivering justice" by metaphor, i.e. using metaphors in various genres of legal discourse (Berger, 2002; Berger, 2007; Gurnham, 2016; Larsson, 2017; Li, \& Xiao, 2017; Simon, 2001 etc.); (2) those "governing by metaphor", i.e. shaping public thinking about various aspects how criminal justice functions (Armstrong, 2009; Kellig, 1991; Kendall-Taylor, \& Haydon, 2014; Potter, 2018; Thibodeau \& Boroditsky, 2011; Walker, 2011; Young, 1996 etc.), and (3) those "professionally communicating" by metaphor, i.e. depicting the most common conceptual metaphors employed in the authentic discourse by law enforcement officers, judges, and other legal professionals (Holt, \& Johnson, 2010; Stevanovic, 2014). 
The theoretical background of the paper is predominantly based on the works by Lakoff and Johnson (see Lakoff \& Johnson, 1980a, 1980b, 1980c). The authors' definition of metaphor and the notion of the target and the source domains is adopted in our study. The analysed conceptual metaphors of the concept 'crime' are assessed and grouped with respect to their classification as structural, ontological, and orientation ones. Structural metaphors mean that "the structures of the source domain are systematically mapped onto the target domain" (Li, \& Xiao, 2017, p. 1066). Ontological metaphors are considered as "ways of regarding events, activities, feelings, thoughts, etc., as entities and substances" (Lakoff, \& Johnson, 1980, p. 25). Orientation metaphors "give a concept a spatial orientation": up - down, in - out, front - back etc". (Lakoff, \& Johnson, 1980, p. 14).

It is a widely shared assumption that media plays a significant role in defining what the general public understands about various social issues, among them crime is inarguably number one. Media texts are a source of cognitive spaces where CMs of the concept 'crime' exist, performing important social-cultural functions. In case of texts devoted to various aspects of law enforcement system, CMs are primarily used to perform the manipulative and axiological functions aiming at the ideological impact on the public mind "governing through metaphors" (Kendall-Taylor, 2014, p. 13; Simon, 2002, p. 1053).

\section{Methods}

Since this paper focuses on the U.S. media discourse about crime, we turn to the metaphorical expressions conceptualising it in 232 articles chosen from the American periodicals: City Journal (CJ) (1991-2013), Atlanta Journal Constitution (AJC) (2001-2015), The Daily News (DN) (2015), The Houston Chronicle (HC) (2015), The Huffington Post (HP) (2013), The New York Times (NYT) (2015), The Washington Post (WP) (2015). Our corpus of observation data consists of 1213 fragments of media texts containing the concept 'crime'. Even though media texts of our research corpus depict different kinds of crimes, our analysis indicates that certain conceptual metaphors are employed in the U.S. media discourse, while thinking and reasoning about the concept of 'crime' as a social phenomenon. Qualitative contextual analysis has allowed identifying the full range of CMs of the concept 'crime' verbalised by different metaphoric expressions in the corpus, and quantitative analysis of the researched data has helped to find out what source domains of the concept 'crime' prevail in popularisation of it in the U.S. press.

\section{Results and Discussion}

The orientation metaphors of the concept 'crime'. We classify orientation metaphors of the concept 'crime' according to the following types: 1) 'few crimes (= crime is down)'; 2) 'a lot of crime (= crime is up)'; 3) 'a lot of crime (= crime moves to the centre)'; 4) 'a lot of crime (= crime moves from the centre)'; 5) 'a lot of crime (= crime moves backwards)'. All the above mentioned CMs feature the orientation of the concept 'crime' in space: up - down, forward-backward, from the centre - to the centre, and they are used to represent statistical data of the crime rates, various tendencies of crime decline and growth in particular regions of the USA.

The dominance of the CM 'few crimes (= crime is down)' is apparent in our research data (477 instances of collocations verbalising it). The movement of the crime down can be both uncontrolled, e.g. : crime begins a steady downward trajectory; crime comes down, declines, decreases, diminishes, dips, drops, falls, goes down, plummets, plunges, slumps; crime collapse; crime decline; crime decrease; crime drop; crime drop-off; crime fall; downturn in crime; downward trend in crime; dwindling crime; falling crime) or controlled, e.g.: bring down crime; bring crime to lows; curtail crime; force crime down; lower crime; push crime down. Important indicators of crime dynamics are its speed and trajectory of movement. For instance, CM 'crime slumps' creates the impression of the precipitous drop of crime that corresponds to the fast lowering of its rate; in contrast, CM "crime begins a steady downward trajectory" emphasises a slow decline of crime rates. Crime rates can also reach the lowest level, e.g.: Crime in America hit a 35 year low in 2008 (Walker, 2011, p. 3), and stay at there for a certain period of time, e.g.: crime is down/low; remains/stays down.

High frequency of CM 'few crimes (= crime is down)' in comparison with other orientation metaphors can be explained by the authors' attempts to exploit it not only for depicting actual positive statistic crime trends but also for picturing a virtual reality of taking crime rate under control.

Orientation CM 'a lot of crime (= crime is up)' occupies the second place in our corpus (240 instances of lexical collocations) and features negative tendencies of crime increase. Crime can move up, e.g.: climbs, escalates, grows, goes up, increases, is on the rise, jumps, rises, rockets up, shoots up, skyrockets, spikes, springs up, ticks upward; crime boom, crime increase, crime jump, crime uptick; skyrocketing crime; it can reach its highest level, e.g.: peak of crime; crime peaks, remains at peak, and stay there for some period of 
time, e.g.: crime is up; crime remains high, soars, stays up; sky-high crime, soaring crime. Crime upward movement can be fast, e.g.: crime jump, crime spike, or gradual and slow, e.g.: crime grows; spiralling crime.

The other three orientation CMs: 'a lot of crime (= crime moves backwards)', e.g.: crime turnaround; crime resurgence; crime rollback; crime comes backwards), 'a lot of crime (= crime moves to the centre)', e.g.: crime concentrates; epicentre of crime and 'a lot of crime (= crime moves from the centre)', e.g.: crime scatters; crime spreads out; dispersion of crime, are scarcely verbalised in the researched material (by 16, 3 , and 3 instances of metaphoric collocations, respectively). CM 'a lot of crime (= crime moves backwards)' accentuates the growth of crime rate after its temporary decline; $\mathrm{CM}$ 'a lot of crime (= crime moves to the centre)' highlights the increase of crime on a particular territory (e.g., city suburbs); $\mathrm{CM}$ 'a lot of crime (= crime moves from the centre)', reflects the spreading of a particular kind of crime in the locality, formerly known as safe.

The structural CMs of the concept 'crime' are represented by the following types enlisted here in the order of their decreasing frequency of occurrence in our research data: 1) 'crime is an enemy' (239 collocations), the source domain - 'war'; 2) 'crime is an element of nature' (76 collocations), the source domain - 'nature'; 3) 'crime is a disease' (61 collocations), the source domain - 'disease' 4) 'crime is a weed' (43 collocations), the source domain - 'vegetation'; 5) 'crime is goods' (24 collocations), the source domain - 'business'; 6) 'crime is a hazardous substance' (18 collocations), the source domain - 'chemical substances'.

The structural CM 'crime is an enemy' depicts crime as an adversary against whom a war is waged, e.g.: Forty years ago, conservatives and liberals disagreed about how to fight crime (CJ, 2013, winter). This $\mathrm{CM}$ is verbalised by the following metaphoric collocations: the war on crime; full-scale, long-running war against crime; suppression of crime; combat crime. The crime-as-an-enemy has both a human likeness, e.g., crime has a human face, and an evil personification, e.g.: Police keep the beast at bay, while citizens are non-combatants; On one side are citizens, on the other, forces of evil, between them, the thin blue line of heroes (CJ, 1991, autumn).

In this war on crime, ordinary Americans are protected by the U.S. law enforcement officers, e.g.: The troops in America's crime war are the men and women of law enforcement (HP, 2013, 3 Mar). For successful preventive measures, the police have to resort to various tactics, use special means and weapons, e.g.: crime-busting strategies; to fight crime with constantly evolving tactics and deployment; Communities across Southern California have a new weapon in the struggle against crime (CJ, 1996, spring); I assure you that $\langle\ldots>$ we are using every tool in our arsenal to combat crime (WP, 2015, $27 \mathrm{Nov})$; But crime could not be conquered without maximum intelligence sharing (CJ, 2001, autumn). There are special tactics surveillance - that is effective in the war against crime, e.g., surveillance deters crime.

The crime-as-an-enemy has not only the defensive nature but also takes the offensive character, e.g.: crime kills cities; violent crime bludgeons New Orleans; citizens were under siege from crime; In ghetto neighbourhoods, where crime raged most fiercely, the fear was worst $<\ldots>$ (CJ, 2013, winter). Some areas become the so-called "hotbeds" where clashes between the police and criminals take place, e.g.: crime hot spot; $<\ldots>$ the area that had recently been prey to such crimes; Murders are so common we have become numbed to their sting. This is Iraq right here in New Orleans (CJ, 2005, autumn). The dwellers of such tough districts become hostages to the criminal world, e.g.: crime-ridden city; The sooner the truth about policing gets out, the more lives will be saved, and the more communities will be allowed to flourish freed from the yoke of crime. (CJ, 2002, spring).

The U.S. society is waging a permanent war on crime. Periodically, law enforcement agencies manage to succeed in their fight against crime in separate areas, e.g.: Over the last eight years, the New York Police Department waged the most successful war on crime in the city's history (CJ, 2001, autumn); Attacking crime has paid big dividends to New York, kindling a new vitality throughout the city (CJ, 1998, winter); Mayor Rudolph Giuliani's conquest of crime in the 1990s (CJ, 2011, spring).

The source domain 'disease' demonstrates a high potential of the concept 'crime' in the research data, activating the structural $\mathrm{CM}$ 'crime is a disease'. If to take into account the CM 'society is a person' (Kooistra, 1989, p. 122; Stevanovic, 2014, p. 130), the reinterpretation of the notion 'crime' as a disease or virus is logical. From a sociological perspective, crime is considered to be "an integral part of all healthy societies" (Stevanovic, 2014, p. 131), but it becomes "dysfunctional (harmful to society) when its rate is unusually high or low" (ibid.) Many cultures treat crime and disease as forms of social deviation or pathology in the sense that the sick and the criminals disrupt society's normal functioning (Gubby, 2014, p. 18; Hanne, 2016, p. 35; Marmor, 2016, p. 266). 
The correlation of crime with a virus (CM 'crime is a virus') can be explained by the fact that viruses are self-replicating organisms which change their form and inflict harm. Such a reinterpretation of the notion 'crime' gained popularity in the mid-80s of the last century due to the global spread of HIV infection which is apt to ruin human life: "HIV "blights lives" as crime does" (Young, 1996, p. 8). This CM is verbalised by the following collocations and constructions: crime is a virus; the blight of crime; crime is a social ill; national epidemic; crime endemic; contact with crime; crime is contagious; diffusion of crime; the spread of crime; crime outbreak.

The CM 'crime is a disease' is also based on the correlation ('mapping') of elements from plague - an infectious disease that historically occurred in large outbreaks and had a high level of mortality, e.g.: the plague of crime; a city plagued by high crime. Crime strikes not only separate members of social communities but streets, areas and whole cities, e.g.: Even as a young councilman, he had tried to draw attention to the crime plague by camping in a trailer on street corners known for their drug trade and, later, by moving into a crimeblighted public-housing complex (CJ, 2006, summer). Localities with the highest crime rate are 'hot spots' of this "disease", e.g.: Though not a hotbed of crime, Minnesota has come up with a bold new approach to juvenile violence (CJ, 1995, autumn); New Orleans area continues to log murder after murder. Something must be done to curb the violence festering in New Orleans (CJ, 2005, autumn). If the attempts to stop crime fail, the crime-virus tends to spread further on, e.g. And now, the crime that has festered out of control in poor and minority neighbourhoods is cascading into the rest of the city (CJ, 2002, winter).

In correspondence with the cases of epidemic of a dangerous infectious disease, the law enforcement agencies take measures to deter the spread of this virus and to prevent it, e.g.: The more law enforcement officers you have out there doing proactive crime control and prevention will give businesses and residents more comfort in their security (AJC, 2001, 15 Mar); <..> higher levels of informal social control operate as barriers to contagion, while the low levels allow crime to spread more freely (CJ, 2002, winter). The law enforcement officers "are symbolised as scientists, seeking a vaccine against or a cure for the virus that is crime", and criminals find their reinterpretation as "the bearers of disease, as evil" (Young, 1995, p. 8).

The CM 'crime is a chronic condition' represents crime as a permanent state, the development of which can get worse, e.g.: Further, the city can't just temporarily ramp up its policing resources whenever it detects a "violent crime wave," as it has done for decades; rather, it must treat crime as a chronic condition, as New York does (CJ, 2007, spring). In correspondence with a cancer tumour, crime destroys the society from inside, e.g.: Nonviolent crime also metastasized on Skid Row, fed by government welfare (CJ, 2007, autumn). Comparable with a disease, crime has symptoms - rash, festering, e.g.: violence festering in New Orleans; the rash of crime.

The CM 'crime is an element of nature' is based on the reinterpretation of the source domain 'nature'. Elements of nature can have various forms, thus the relating structural CM has three kinds: 'crime is a wave', 'crime is a flood', and 'crime is a fire'.

The CM 'crime is a wave' is frequently denoted by the noun wave with attributes or collocations meaning 'wave', 'surf', 'ebb' and 'tide' (42 collocations). In correspondence with little waves that break on the shore and ebb, the crime rate tends to increase and decrease, in other words, the fluctuation of statistic data is compared with tide and ebb, e.g.: tidal wave; walking crime wave; crime surge; crime upsurge; fluctuation in crime; crime laps. But huge waves can have a ruinous force and destroy whole cities, e.g.: crime tsunami; $<\ldots>$ the murderous crime wave seemed to grip the city just hours after the eye of the storm had passed (CJ, 2005, autumn). This CM is used both to illustrate statistical data and to emphasise the danger that exists in any society in case of the crime surge.

The CM 'crime is a flood' is represented by the nouns flood and stoke, by the phrasal verb spill out, e.g.: The lunchtime shooting sent witnesses scrambling for cover outside the Twin Peaks Restaurant where a shootout spilled out into the parking lot between three known "rival criminal biker gangs ( DN, 2015, 15 May ). Similarly to the flood, when water overflows or inundates land that is normally dry, crime infiltrates all spheres of society. As flood causes damage and destruction, crime inflicts almost any kind and degree of harm.

The CM 'crime is a fire' is represented by the metaphoric collocation crime hot spots. The fire flaring up in some forest plots is apt to destroy everything around that has life; comparably, the crime concentration in a definite neighbourhood turns it into a tough district with deteriorating safety and outflow of city dwellers. Kindling is used for starting a fire; likewise, vices and drugs can vivify crime in neighbourhoods, e.g.: Crack, homicides, and assaults went hand in hand; certain areas of New York became "like a war zone, " <...> (CJ, 2008, spring). Similarly to a fire event, law enforcement forces perform the functions of firefighters and must extinguish the heat source or resort to all measures to minimise the risk of a fire starting, e.g.: The twenty-first-century NYPD combines Kelly's belief in quality-of-life enforcement with a new method of deploying rookie cops to cool down crime hot spots (CJ, 2006, summer). 
Compared to water or air that can cause erosion, crime erodes the social welfare, e.g.: $<\ldots>$ this perfect policy is punishment in what he rather optimistically calls "the community" (the cohesion of which, of course, crime has done so much to erode) (CJ, 2003, spring).

The elements of water, fire and wind are uncontrolled by a man who can only resort to certain measures to reduce a predictable damage or flee to escape danger. Thus, the structural metaphor 'crime is an element of nature' is frequently employed to accentuate uncontrollability and insubordination of crime to man's will. Authors who write about crime typically draw a parallel between it and a huge wave or flood when they mean to emphasise the ineffectiveness of the tools /measures / policies resorted to by the authorities to combat such a crime as corruption.

The source domain 'vegetation' activates the structural CM 'crime is a weed' (43 metaphoric collocations). In accordance with this reinterpretation, crime is ascribed a correlation with a weed, unwanted wild plant that grows and blooms in competition with cultivated ones, e.g.: roots of crime; crime grows; crime flourishes; crime thrives; There was a pretty significant crime problem that just blossomed (HC, 2015, $12 \mathrm{Feb}$ ). But crime as a harmful weed needs constant pulling up, removing, destroying etc., e.g.: cut crime, slash crime, Under cover of political instability, every kind of crime flourishes (CJ, 2000, winter); The weed of crime bears bitter fruit (CJ, autumn 2005). Pulling up weeds is hard work, but only soil free from weeds will yield good harvest, e.g.: "Pulling up those many weeds [crimes], as painful as that was" he said, "allowed churches, schools, community groups and parents to plant seeds that have grown into healthy neighbourhoods <..." (NYT, 2015, 29 Oct).

The CM 'crime is goods' (24 metaphoric collocations) activates the source domain 'business'. This CM highlights the price of crime for the society, in correspondence with a commodity that has its price, e.g.: Reform would also send a healthy message to the young offenders and their families that there's a cost to crime (CJ, 1998, summer); Crime is expensive. We do well to fight it (AJC, 2015, 11 Feb). Goods are transported/exported; correspondingly, crime can spread to new territories, e.g.: Washington, D.C., has exported some of its crime to surrounding counties in Maryland and Virginia (AJC, 2008, July/August). Goods are accessible to customers; in a similar way, crime is 'accessible' to any individual who chooses to commit it, e.g.: Crime was open for business 24 hours a day (CJ, 2007, winter). Goods are manufactured in various branches of industry; in a similar way, criminals can operate in various spheres, and crime can be directed against various social bodies, e.g.: Decades after the carnage of the Lindsay years, crime remains a political commodity (CJ, 2013, summer). Goods are sold by salespeople who get certain profit in return; the same way, criminals gain benefit from committing a successful crime, e.g.: A new class emerged: crime brokers, who offered peace in exchange for the privilege (CJ, 2013, summer).

The source domain of the CM 'crime is a hazardous substance' (18 metaphoric collocations) is 'chemical substance'. Some chemical substances are explosive, poisonous and harmful to human health. The $\mathrm{CM}$ 'crime is a hazardous substance' diversifies in three kinds:

1) 'crime is an explosive': while mishandled or overheated, explosives can detonate and cause significant destruction; correspondingly, the increase of crime in a particular area can cause a social calamity or damage, e.g.: crime explosion, crime explodes;

2) 'crime is corrosion': a corrosive substance gnaws even metals, just as well as the crime that can make damage to the society, irrespective of social strata, e.g.: But crime here is much more than a physical threat, terrible as that may be. It [crime] is also a social corrosive (CJ, 2002, autumn);

3) 'crime is poison': the intake of poison can have an injurious or fatal effect on a human body, if its effects are not neutralised by an antidote or remedied, in correspondence with crime that can cause irreparable damage, if preventive measures are not taken without delay, e.g.: antidote to crime, crime poisons.

The structural CM 'crime is a hazardous substance' typically accentuates a significant and, at times, a fatal danger to the society, but also implies that taking preventive measures can help to escape or reduce negative consequences.

The CMs representing crime as an enemy, element of nature, disease, weed, goods, hazardous substance highlight such conceptual features as dangerousness, harmfulness, uncontrollability, and despite all of the above, a certain profitability (lucrativeness).

Ontological metaphors of the concept 'crime' have turned out to be the least frequent in the research data, their verbalisers making up $1 \%$ of the overall collocations analysed (10 collocations). These metaphors diversify into the following kinds: 'crime is mire', e.g.: mired in crime; clean crime out; a cesspool of crime; grime; clean after crime took place; 'crime is food', e.g.: cauldrons of crime; fed up with crime; 'crime is a beast', e.g.: unleash crime; crime raged out of control. People can wallow in crime as they can do in the 
mire. Food can tempt people, but its excessive consumption is harmful to health; likewise, crime can entice some individuals as a means of satisfying their needs, but it personifies harm. The crime like an unleashed wild animal conceals danger.

Functions of CMs of the concept 'crime'. Conceptual metaphors singled out in the research data are frequently employed by the media, politicians, and authorities in various genre forms of media discourse. The CMs 'crime is a weed', and 'crime is a disease' represent social nature of crime and introduce the idea of crime control and prevention: continuous collaboration between authorities and society at local communities level (social work with juvenile delinquents, employment, and training programmes for the unemployed, adult education programmes for poverty reduction etc.) relieves the impact of negative social factors that might affect people to commit crime, thus reducing its rate. The CM 'crime is a disease' implies that "the source of crime can be diagnosed (it has an identifiable cause)", and "crime has a cure (there is something that can eliminate crime)" (Allbritton, McKoon, \& Gerring, 1995, p. 612). The comparison of crime with a virus and weed implies a possibility of its growth /spread and deterrence only under the condition of regular soil cultivation/immunisation.

The structural CM 'crime is an enemy' evokes a deep connotation that "crime is the largest internal enemy of a country", and represents the idea of its fight by introduction of large-scale preventive and punitive measures. The manipulative and axiological functions of this CM consist of:

(a) presenting crime as one of the gravest issues that, in addition to its potential danger to the life and health of every citizen, hinders the growth of social well-being. Thus, this CM aims at distracting the public attention from economic problems to gain political dividends;

(b) cultivating intolerant attitude of the society to criminals and approving of crime combat measures by law enforcement agencies, tough actions etc.;

(c) justifying introduction of the government simplified access to personal data and live webcams in public places;

(d) supporting expenditure increase on the law enforcement system, alongside with reduction of public spending.

The use of the military rhetoric and the CM 'crime is an enemy' has gained its particular spread in the US mass media discourse since September 11, 2001, terrorist attacks. The source domain 'war' of this CM personifies conceptual foundations of the U.S. law enforcement agencies. This vision enables to treat one side (law enforcement system) as morally correct, and take off responsibility from law enforcement officers for their actions while carrying out their duties - "disavowal of responsibility for the soldiers who act under superior orders" (Young, 1995, p. 7).

The above considered structural conceptual metaphors model the strategies of crime rate reduction for ordinary Americans who are familiar with them from their own experience or from the media / movies: fight against an enemy, immunisation as a preventive measure to bring down the risk of catching a contagious disease, work in a fruit or vegetable garden.

\section{Conclusions}

By applying cognitive analysis to metaphoric expressions with the meaning 'crime' found out in the U.S. media discourse, three types of conceptual metaphors have been singled out: structural, ontological, and orientation. According to the received quantitative data, orientation metaphors of the concept 'crime' are the most pervasive in the U.S. media discourse (61\% of the total number of collocations), with structural metaphors occupying the second position (38\%), and ontological metaphors being the least frequent (1\%). Orientation metaphors feature the trajectory of crime in space: up - down, forward - backward, from the centre - to the centre, and are used to represent statistics of the crime rate. Structural metaphors 'crime is an enemy', 'crime is the element of nature', 'crime is a disease', 'crime is a weed', 'crime is goods', 'crime is a hazardous substance' model the strategies of crime rate reduction for ordinary Americans. Ontological metaphors 'crime is mire', 'crime is food', 'crime is a beast' highlight such cognitive features of crime as dirt, harm, and danger.

Our further research will focus on the conceptual metaphors that represent the concept 'crime' in the contemporary U.S. legal discourse.

\section{References:}

Allbritton, D. W., McKoon, G., Gerring, R. J. (1995). Metaphor-Based Schemas and Text Representations: Making Connections Through Conceptual Metaphors. Journal of Experimental Psychology: Learning, Memory, and Cognition, 21(3), 612-625. Armstrong, Sarah. (2009). Managing Meaning: The Use of Metaphor in Criminal Justice Policy. http://dx.doi.org/10.2139/ssrn.1508340 Atlanta Journal Constitution (2001, 15 Mar). Retrieved January 24, 2918, from: http://www.ajc.com Atlanta Journal Constitution (2015, 11 Feb). Retrieved January 24, 2918, from: http://www.ajc.com 
Atlanta Journal Constitution (2008, July/August). Retrieved January 24, 2918, from: http://www.ajc.com

Berger, B. L. (2002). Trial by Metaphor: Rhetoric, Innovation, and the Juridical Text. Court Review, The Journal of the American Judges Association, 39(3), 1-9. Retrieved December 11, 2017, from: http://digitalcommons.unl.edu/ajacourtreview/133

Berger, L. (2007). Of Metaphor, Metonymy and Corporate Money: Rhetorical Choices in Supreme Court Decisions on Campaign Finance Regulation. Mercer Law Review, 58. Retrieved November 7, 2017, from: http://works.bepress.com/linda_berger/5/

City Journal (2013, winter). Retrieved December 11, 2017, from: https://www.city-journal.org/html/gop-and-city-13527.html

City Journal (1991, autumn). Retrieved October 7, 2017, from: https://www.city-journal.org/html/crime-and-metaphor-toward-newconcept-policing-12733.html

City Journal (1996, spring). Retrieved October 7, 2017, from: https://www.city-journal.org/html/taking-back-streets-11779.html

City Journal (2001, autumn). Retrieved October 9, 2017, from: https://www.city-journal.org/html/keeping-new-york-safe-terrorists-12197.html

City Journal (2005, autumn). Retrieved October 9, 2017, from: https://www.city-journal.org/html/who\%E2\%80\%99s-killing-neworleans-12429.html

City Journal (2002, spring). Retrieved October 9, 2017, from: https://www.city-journal.org/html/racial-profiling-myth-debunked-12244.html

City Journal (1998, winter). Retrieved October 11, 2017, from: https://www.city-journal.org/html/crime-war\%E2\%80\%99s-nextbattles-11783.html

City Journal (2011, spring). Retrieved October 11, 2017, from: https://www.city-journal.org/html/radical-graffiti-chic-13369.html

City Journal (2006, summer). Retrieved October 11, 2017, from: https://www.city-journal.org/html/new-york-cops-still-finest12951.html

City Journal (2007, spring). Retrieved October 16, 2017, from: https://www.city-journal.org/html/baghdad-bayou-13007.html

City Journal (2007, autumn). Retrieved October 16, 2017, from: https://www.city-journal.org/html/reclamation-skid-row-13041.html

City Journal (2008, spring). Retrieved January 22, 2018, from: https://www.city-journal.org/html/criminal-justice-system-racist-13078.html

City Journal (2003, spring). Retrieved January 22, 2018, from: http://www.city-journal.org

City Journal (2000, winter). Retrieved January 22, 2018, from: https://www.city-journal.org/html/criminal-justice-system-racist-13078.html

City Journal (2013, summer). Retrieved January 22, 2018, from: https://www.city-journal.org/html/stand-your-ground-new-york11238.html

Daily News (2015, 15 May). Retrieved December 4, 2017, from http://www.nydailynews.com/news/crime/rival-motorcycle-gangsbehind-shooting-texas-restaurant-article-1.2225691

Gubby, H. (2016). English Legal Terminology : Legal Concepts In Language. The Hague: Eleven International Publishing.

Gurnham, D. (2016). Law's Metaphors: Introduction. Journal of Law and Society, 43(1), 1-7.

Hanne, M. (2016). Crime and Disease: Contagion by Metaphor. In C. Stanton \& H. Quirk (Eds.), Criminalising Contagion: Legal and Ethical Challenges of Disease Transmission and the Criminal Law. Cambridge: Cambridge University Press. doi:10.1017/CBO9781316135631.004

Holt, E., \& Johnson, A. (2010). Socio-pragmatic aspects of legal talk: police interviews and trial discourse. In M. Coulthard, \& A. Johnson (Eds.), The Routledge Handbook of Forensic Linguistics (pp.21-36). New York, NY : Routledge.

Johnson M. (2010). Metaphor and cognition. In D. Schmicking, \& S. Gallagher (Eds.), Handbook of Phenomenology and Cognitive Science (pp. 401-414). Dordrecht : Springer.

Kellig, G. (1991). Crime and Metaphor: Toward a New Concept of Policing. City Journal. Autumn 1991. Retrieved December 11, 2017, from: https://www.city-journal.org/html/crime-and-metaphor-toward-new-concept-policing-12733.html

Kendall-Taylor, N., \& Haydon, A. (2014). Space to think: Using Metaphor to Expand Public Thinking about Criminal Justice Reform. Studies in Media and Communication, 2 (2), 13-23.

Kooistra, P. (1989). Criminals As Heroes: Structure, Poser, and Identity. Bowling Green, OH: Popular Press.

Kövecses, Z. (2010). Metaphor: A Practical Introduction. 2nd edn. Oxford: Oxford University Press.

Lakoff, G, \& Johnson, M. (1980a). Conceptual metaphor in everyday use. The Journal of Philosophy, 77, 453-486.

Lakoff G., \& Johnson, M. (1980b). The Metaphorical Structure of Human Conceptual System. Cognitive Science, 4, 195-208.

Lakoff, G., \& Johnson, M. (1980c). Metaphors we live by. Chicago: University of Chicago Press.

Larsson, S. (2017). Conceptions in the Code: How Metaphors Explain Legal Challenges in Digital Times. Oxford: Oxford University Press.

Li, Chen, \& Xiao, Han (2017). A Contrastive Study of Conceptual Metaphor in Chinese and American Courtroom Discourse. Theory and Practice in Language Studies, 7 (11), 1065-1074. DOI: http://dx.doi.org/10.17507/tpls.0711.15

Marmor, A. (2014). The Language of Law. Oxford: Oxford University Press.

Potter, R. (2018). The "Crime as a Disease" Metaphor: Vision, Power, and Collaboration in Social Problems Research. In M. Hanne \& R. Weisberg (Eds.), Narrative and Metaphor in the Law (pp. 200-219). Cambridge: Cambridge University Press. doi:10.1017/9781108381734.014

Richard, I. (2014). Metaphors in English for Law: Let Us Keep Them! Metaphor Studies in the English Language, 8. Retrieved January 4, 2018, from: https://lexis.revues.org/251

Simon, J. (2001). Governing through Crime Metaphors. Brookline Law Review, 67, 1035-1070.

Smith, M. R. (2007). Levels of metaphor in persuasive legal writing. Mercer Law Review, 58, 919-947.

Stevanovic, M. (2014). Hot on the Trail of Deadly Criminals: Conceptual Metaphors Employed by Law Enforcement Officers. British and American Studies, 20, 29-36. Retrieved December 17, 2017, from: https://litere.uvt.ro/publicatii/BAS/pdf/no/bas_2014.pdf

The Houston Chronicle (2015, 12 Feb). Retrieved January 18, 2018, from: http://www.chron.com

The Huffington Post (2013, 3 Mar). Retrieved January 18, 2018, from: http://www.huffingtonpost.com/crime/

The New York Times (2015, 29 Oct). Retrieved January 18, 2018, from: http://www.nytimes.com

The Washington Post (2015, 27 Nov). Retrieved December 13, 2017, from: https://www.washingtonpost.com/opinions

Thibodeau, P. H., \& Boroditsky L. (2011). Metaphors We Think With: The Role of Metaphor in Reasoning. PLoS ONE, 6(2). Retrieved November 3, 2017, from: https://journals.plos.org/plosone/article?id=10.1371/journal.pone.0016782

Walker, S. (2011). Sense and Nonsense About Crime, Drugs, and Communities: A Policy Guide. Belmont, CA: Wadsworth Gengage Learning.

Young, A. (1996). Imagining Crime. London, Thousand Oaks, CA: Sage Publications. 